\title{
Catahoula Leopard Dog
}

National Cancer Institute

\section{Source}

National Cancer Institute. Catahoula Leopard Dog. NCI Thesaurus. Code C53757.

The Catahoula Leopard Dog is a herding dog with a short, single coat and a deep chest. Some coats can be course, but most are short and tight. The coat is colored in a merle or black/tan pattern. Height: 20-26 inches (51-58 cm.) Weight: 55-80 pounds (16-37 kg.) 